\title{
The bourgeoisie and the scholar
}

\author{
JOEL MOKYR \\ Northwestern University \\ Tel Aviv University
}

Deirdre McCloskey is a true sui generis in our intellectual universe. In the latest (and last, by her own promise) installment of her Bourgeoisie trilogy, she had brought together many of the ideas proposed in the two earlier volumes, as well as in a long stream of essays and lectures. She is an economist like no other economist: fiercely opposed to the domination of game theory, vociferously suspicious of the use of mindless statistical significance in empirical work, and resistant to the "institutional turn" in economic history. In these three volumes she effectively demolishes the idea of historical materialism. Economic forces do not determine what people believe and think, she maintains; it's the other way around. Ideas determine how people act and behave, whether they will invest or waste, accept bribes or serve the public honestly, whether they will be makers or takers, think outside the box or remain loyal to age-old conceptions, and hence whether the economy will be static and stagnant or dynamic and vibrant.

Specifically, she asks this question about modern economic growth, or what she calls "the Great Enrichment" (a term that is to be preferred to "the Great Divergence", which stresses the gap opening up between East and West in the eighteenth century rather than the miraculous rise in living standards). The argument, in a nutshell, is that in a few core areas in the western part of Europe, the prestige and social standing of economically active and ambitious "bourgeois" agents-merchants, entrepreneurs, innovative industrialists and farmers, bankers and so on-began to increase. The Bourgeois "revaluation" or "deal" is what accounts for modern economic growth. "There was a sharp rise in society's receptiveness to improvers" (p. 472). Slowly, and in the face of much resistance, people began to shed the notion that trade and

AUTHOR's NotE: The following is based in some part on my forthcoming $A$ culture of growth: the origins of the modern economy, Princeton University Press 2016, in press. The financial support of the International Balzan Foundation and the Center for Economic History at Northwestern is gratefully acknowledged. Deirdre McCloskey's comments on an earlier version led to many improvements. 
voluntary transactions between consenting adults were improving for all sides. The world was understood to be positive-sum.

In other words, the culture (a word she eschews, but that seems unavoidable here) of society as a whole mattered, not just the beliefs of the actors themselves. Not much else changed in Europe before the Industrial Revolution, she feels, that would explain the take-off that led into the Great Enrichment. "We must look to ideas, which did change at the right time in the right places, and greatly", as she puts it (p. 470). I cannot possibly disagree: indeed, my own Gifts of Athena (2002) and my Enlightened economy (2009) make a similar point. But McCloskey emphasizes a different angle. The hierarchy of values in every society determines what careers young men and women choose and how hard they try to succeed. In a military-oriented society they will stress physical prowess, in a scholarly society they will strive to become learned in the books that matter. In a capitalist society in which commerce and economic success are respected, entrepreneurship and profitable innovation will thrive and economic prosperity will ensue. But profits were not everything, much less the only thing. People are not just driven by greed ("prudence" in her somewhat quaint nomenclature), they have ethical beliefs and care what others think of them. For a scholar trained in modern economics, this is a bold, heterodox thought. But it may have the advantage of being correct.

In making her arguments, McCloskey treads on grounds rarely visited by economists: she cites novelists, philosophers, playwrights, political theorists, poets, The theory of moral sentiments (the "other" Smith masterpiece that most economists skip) (1976 [1759]), and what not. If that makes her arguments more persuasive to her fellow economists or not remains to be seen. Indeed, at times her tone slides into a condescension that some readers may find off-putting. I have read all these books in the humanities and philosophy, she says, and "they" have not. So they are in no position to question my conclusions. One scholar is advised by her to re-read The theory of moral sentiments-"slowly." For someone who wrote the book on The rhetoric of economics (1985) and who has repeatedly urged economists "don't sneer", this patronizing tone is an unexpected and perhaps unwise tactic. Especially the late Douglass North, one of the great pioneers of economic history (and more broadly, social science history), comes in for McCloskey's scorn. Samuelsonian economics, or "Max U" as she contemptuously calls it-roughly equivalent to the lion's share of the 
practice of economics in academic circles-fares little better under her withering critique. But then, one does not get to be Deirdre McCloskey unless one marches to the beat of one's own drum, even if it sounds at times a bit off to others. McCloskey's idiosyncratic if often endearing writing style, however, should not fool her readers to take her message lightly. This is a book of enormous learning, penetrating original insight, and yet written with a disarming charm, and a good cheer that is often utterly irresistible. All the same, the issues that professor McCloskey takes on are momentous and complex, and she full-well expects others to disagree on some matters-and so I shall.

Professor McCloskey cites me (p. 511) as having written that "economic change depends, more than most economists think, on what people believe". That message, obvious as it may sound, needs to be stated and re-stated, to rid ourselves of the relics of historical materialism. McCloskey has stated it more eloquently and emphatically and documented it more copiously than I ever can. In her crucial part VIII, chapters 51-55, she states her central position: words and ideas caused the modern world. Moreover, she correctly identifies the critical centuries between Columbus and Newton's Principia as the formative years in which everything changed and an irreversible cascading movement toward an increasingly productive technology was set in motion. So far so good. But it is the beginning of a research program, not the end of it.

Where disagreement sets in is what kind of beliefs and knowledge mattered here and whose beliefs. Professor McCloskey argues that at some point in early modern Europe, society began to honor the "bourgeoisie"-merchants, investors, high-skill artisans, and speculators, giving them a respect and a social standing that later generations, led by a retrograde "clerisy," no longer could muster uniformly. Instead, left-wing intellectuals, led by Marxists, turned the bourgeoisie into a bête noire and a scapegoat for all of society's ills. But by that time the engine of growth had been set into motion, and a series of self-enforcing irreversible changes had occurred that led to the Great Enrichment (McCloskey seems to prefer the term "betterment"-I suspect few will follow her in that; but it is still better than "betterocracy," a dreadful neologism proposed on page 512). Her argument is supported by an enormously rich and diverse body of evidence from an almost bewildering array of sources, spread over a large number of short but pungently titled chapters. My favorite ones 
are chapters 35-36 entitled "The Dutch preached bourgeois virtue" and "And the Dutch bourgeoisie was virtuous". The Dutch Golden Age is indeed a critical juncture in her account. It was not just greed or profit maximization that dominated this virtuous society, she shows, it was ethics, charity, temperance, tolerance, perhaps even "love". That is the essence of being bourgeois.

What is missing in her account, quite on purpose obviously, is much attention to the great minds and intellectuals who changed the conversation of learned men and women in Europe in the centuries before the Industrial Revolution. Some of the greatest minds that created the age of modernity-and with it modern prosperity-deserve nary a mention. These choices indicate the strengths but also the flaws in McCloskey's analysis. On page 501, she provides her list of the people whose rhetoric rang in the age of improvement. They include Enlightenment thinkers such as Hume and Rousseau, politicians such as Pitt and Napoleon, and writers such as Wollstonecraft, Martineau, and Manzoni. Oddly missing are any Dutch names, despite her repeated statements that it all started in the Netherlands and Britain. It is one thing to leave out the great scientists of the age (see below), but for a book so concerned with the rise of modern ways of thinking, how could she leave out a discussion of Spinoza who by many accounts (most recently the massive trilogy by Jonathan Israel) as summarized in Israel (2010) was the "first modern thinker"-and Dutch to boot.

For a book so concerned with ideas, then, it is odd that many of the people whose ideas most influenced the "new thinking" in early modern Europe are remarkably absent: Descartes, Galileo, Huygens, Newtonnone of them seem to make much of an impact on her account of the intellectual preparation needed for the Great Enrichment. Part of the reason for this, as she repeatedly stresses, is that she believes that science played no role in the Great Enrichment until it was well underway. This is where this massive and learned tome is at its most vulnerable. McCloskey simply dismisses the impact of science and the scientific revolution as immaterial and of little practical value until "the 1960s [when] we wanted to navigate our way to the moon” (p. 506).

It is never quite clear on what grounds this dismissal is warrantedsurely one has to do more than just ask the schoolchild's question "how much science was needed for a spinning jenny"? There is a serious scholarly literature that discusses this point at great length, yet apart from a nod to the eminent historian Margaret C. Jacob and myself-both 
dismissed as mistaken on the matter- there is no serious engagement with the literature that links scientific progress to the Great Enrichment, from Musson and Robinson's classic Science and technology in the industrial revolution (1969) all the way to the more recent books by Floris Cohen (2012) and David Wootton (2015).

Nobody argues that the entire Industrial Revolution is explained by scientific progress, nor that the connection between scientific breakthroughs and technological progress did not become more powerful as time went on in the nineteenth and twentieth centuries. Perhaps the emphasis placed by Jacob and Stewart on "Newtonianism on the shopfloor" (2004) seems a bit overdone. But the dismissal of any role of formal and codified knowledge in advancing technology and the discourse that led to the triumph of the Baconian program in the West is simply unsupportable.

The examples of science in the service of industry as early as the first part of the eighteenth century and with ever greater force during and after the Industrial Revolution are just too important to ignore. The example of the work of French mathematicians and English experimentalists on hydraulics is well known-it led to much improved water mills and later turbines (Reynolds 1983). So, of course is the work of eighteenth-century Swedish and French chemists on the use of chlorine (a recently discovered substance) in the service of the cotton industry. Less well-known but of great importance is research in pneumatic chemistry, which led to the controlled burning of gas and the gas-lighting industry, one of the most successful and dramatic advances of the Industrial Revolution (Tomory 2012). The budding science of geology turned useful when it was realized that fossils could be used to prospect for coal (Winchester 2001). Steam power, of course, presents the odd mixture of formal propositional knowledge and the kind of high level of imaginative craftsmanship that men like Watt, Smeaton and Wedgwood embodied. But without the "experimental philosophy" of natural scientists such as Torricelli, von Guericke, Huygens, Boyle, and Denis Papin, the critical understanding of atmospheric pressure and vacuum would simply not have come about. Even McCloskey's favorite artisan-inventor, John Harrison, who perfected the marine chronometer to resolve the age-old longitude at sea problem, could not possibly have done his work without the work of mathematically-trained geographers and astronomers-the first one was the Dutch (more accurately Frisian) astronomer and mathematician Jemme Reinerszoon, 1508-1555, known 
as Gemma Frisius, who first suggested that what Harrison did was possible.

In short, the kind of formal and codified natural philosophy, that became what we call today "modern science", arose in the very period McCloskey sees as the time when the conversation in Europe changed. Yes, intellectuals mattered to the Great Enrichment, but it seems almost unimaginable in that context to write at great length about Jane Austen and leave out Joseph Priestley, the discoverer of oxygen, the inventor of carbonated drinks and pencil erasers, a liberal and progressive yet deeply religious enlightenment philosophe. Modern chemistry as we know it now was formulated by Antoine Lavoisier. Within a generation his new chemistry already found a myriad of uses through the work of, among others, Lavoisier's countryman Michel-Eugène Chevreul, who discovered the nature of fatty acids and turned the manufacture of soap and candles from an art into a science. As director of dyeing at the Manufacture des Gobelins, he had a direct interest in the chemistry of dyes and colors following the original work on the chemistry of dyeing that had been carried out by his predecessor at the Gobelins, Claude Berthollet, the inventor of chlorine bleaching and one of Lavoisier's most illustrious followers. Long before the twentieth century-when McCloskey concedes that the scientific discourse began to matterGerman chemists in Giessen developed organic chemistry with enormous effects on industry and agriculture.

Even more important than the actual scientific insights of the seventeenth century were the meta-ideas that gained acceptance in the intellectual discourse of early modern Europe on how to gather and evaluate propositional knowledge. Among those, the ones with the most dramatic impact for the eventual Great Enrichment were three. First, the triumph of experimentalism, the understanding that results from experiments - contra Aristotle-were a valid way of verifying hypotheses in natural philosophy. Experimental science required precision in both workmanship and materials, standardization of terminology and units, and a clear and detailed communication of experimental work so that it could be reproduced and verified. Second, research became more formal, mathematical, and quantitative. Galileo famously wrote that the book of nature was written in the language of mathematics, and by 1650 it was impossible to do serious physics without a strong training in mathematics. Finally, science developed an inductive side when formal mathematical analysis would not do; plants and planets could be 
observed, counted, catalogued, and classified. Patterns and regularities would emerge, perhaps, to show how nature worked.

There is no contradiction between McCloskey's "Bourgeois Deal" and her emphasis on ethical beliefs and the growing influence of the Baconian ideal of science in the service of society. Creative minds wanted to be recognized in society, and the changing hierarchy of values affected the social standing of natural philosophers and intellectuals. Eighteenth century Britain honored Newton more than Marlborough. To be sure, patronage-the driving factor on the demand side of the market for ideas-started off largely as an aristocratic venture, but the urban bourgeoisie and merchants demand for information and interest in science (did "curiosity," once a vice, begin to count as a "virtue"?) added fuel to the engine of progress, as documented by Harold Cook in his Matters of exchange: commerce, medicine and science in the Dutch golden age (2007).

McCloskey's "honor to the bourgeoisie" story will be incomplete unless we recognize the great and unique intellectual transformation that set early modern Europe apart from all other societies that preceded it and coexisted with it: it was losing its paralyzing respect for the iron grip of past learning. For some reason, humans seem to be hardwired to honor the wisdom of their ancestors and to feel somehow inferior in the face of past learning. Whether the Talmud, the Koran, Confucius, or Aristotle and Galen, there seems to be a pervasive belief that the truth had been revealed to our ancestors, and that wisdom was to be found by poring over their writings and exegesizing them until the true meaning was revealed. In the sixteenth century, that belief was irreparably weakened. In 1580 an Oxford Don could still be fined five shillings by teaching something that was contradictory to the writings of Aristotle. But Oxford was behind the curve: by that time the classical canon had come under fire from every corner. The intellectual world of the fifteenth century was still in the shadow of classical learning, but in the sixteenth century and beyond, it had morphed in the world of insolent rebels such as Paracelsus, Harvey, Ramus, Brahe, Boyle, and so many others. Driven by new observations and information, they ripped the classical texts in physics and medicine to shreds, and subjugated them to what they believed to be persuasive evidence and logic. A new world of useful knowledge was created.

As professor McCloskey would say, the rhetorical rules of what was true and what was not changed, since they themselves were the subject 
of the intellectual discourse. The line "Aristotle (or the Bible) said so, hence it must be true" was no longer acceptable. The famous struggle between the "moderns and ancients" that took place in this period ended with a resounding triumph of the moderns. The works of classical antiquity may have retained a place in the curricula of universities, but as an authoritative source on anything having to do with the natural world they were decisively dethroned. Once the leaden burden of the authority of Aristotle, Ptolemy, Galen, and other classical writers was lifted and the age of in nullius verba began, modernity dawned.

McCloskey is of course correct in pointing out that at first the tangible achievements of science were modest. Many scientific areas in which progress would yield its highest fruits in the Great Enrichment turned out to be much messier and more complex than expected. The hopes that eighteenth-century post-Newton scientists had to Newtonize chemistry, medicine, biology, and agricultural science were all disappointed in the short run. Dr Johnson, one of McCloskey's heroes (chap. 17), writing in The Idler (1759), expressed the disappointment of the age:

When the Philosophers of the last age were first congregated into the Royal Society, great expectations were raised of the sudden progress of useful arts; the time was supposed to be near when engines should turn by a perpetual motion, and health be secured by the universal medicine... The [gout] and [stone] were still painful, the ground that was not ploughed brought no harvest. [...] The truth is, that little had been done compared with what fame had been suffered to promise; and the question ["what have you done?"] could only be answered by general apologies and by new hopes, which, when they were frustrated, gave a new occasion to the same vexatious enquiry.

In 1759, as in 1776, the Great Enrichment was still more a hope and an aspiration than a reality. How to make cheap steel, how to tame electricity, how to communicate over larger distances at lightning speed, how to end the scourge of smallpox, and what made crops grow more abundantly and reliably were all still problems with which the best minds of the eighteenth century were struggling. In the century following The wealth of nations they were all solved. Can one really tell the story of the Great Enrichment without them?

The other problem I see with McCloskey's book is the question of "why". The richness of the literary and historical detail she supplies to 
describe and document the rise of the "Bourgeois Deal" should not blind us that, odd for an economist, the main line of the story is underdetermined. It is all good and well to focus on "discourse", rhetoric, and conversation in explaining how attitudes and beliefs changed. But an economist will remain dissatisfied: what is the true driver in this model? Why and how did the discourse change and the "Bourgeois Revaluation" prevail in Northwestern Europe in the sixteenth and seventeenth century? Why not elsewhere, or at some other time? Why in Europe and not in China? And if in Europe, why not in Poland, Portugal, Sicily, or the Balkans? Do we have any kind of model to explain why certain themes and values prevailed and others were discarded? Here I found the 787 pages of Bourgeois equality less than helpful. There is description: mental frames were altered, new neural pathways were laid down in people's brains (p. 525). On page 152, when the question is posed explicitly, the answer given is "the egalitarian accidents of 1517-1789". It was "a happy accident of circumstances" (p. 465). Or on page 640, the final chapter that is supposed to sum it all up: "Once upon a time a great change occurred, unique for a while to Europe, especially after 1600 in the lands around the North Sea". Or on page 439: "Europe was merely lucky [that harmful intervention of the state was overcome by] trade-tested, markedly positive-sum betterments". Chapter 50, which takes on the issue of "why not elsewhere" is uncharacteristically full of words such as "mystery" and "puzzle". Perhaps a volume 4 of the Bourgeois project is needed, after all.

Yet it is possible to make some progress. McCloskey adopts a concept of 'trade-testing' (as in "trade-tested betterment”). In and of itself, I find the qualifying "trade-tested" improvements rather puzzling. Does it mean that they sell? Much improvement, from the works of Spinoza to those of Schubert can hardly be judged as being "tradetested". And many things were trade-tested yet hardly qualified as improvements. But what may help our understanding here is the concept of a 'market for ideas'-a concept proposed as early as 1962 by Michael Polanyi (1962) and later elaborated on by leading economists such as George Stigler (1965) and Ronald Coase (1974). New ideas are placed on the menu of the social conversation all the time. If its proponent, or one of her supporters, persuades another person to change his mind about some belief or supposition, a 'sale' has occurred. Of course, no money changes hands in this 'transaction'. Yet creative intellectuals understand and play the persuasion game all time- 
perhaps nobody better than Deirdre McCloskey herself. The most desirable attribute for an intellectual to attain is not to be rich or "tradetested", not even necessarily to be 'correct', but to be influential. John Calvin, Francis Bacon, and Isaac Newton, each in their own way, influenced their times more than almost anyone else. Indeed, in the market for ideas they can be regarded as 'cultural entrepreneurs'. The test of a well-functioning market is that it allows successful entrepreneurs to come into their own. Paracelsus, Harvey, Descartes, Galileo, and Leibniz were all intellectual superstars, in a world in which the economics of superstars became increasingly applicable. But right behind them marched a small army of thousands of famous and obscure innovators-intellectuals, physicians, craftsmen-who placed new items on the ideational menu. Innovation became attractive, because it held the possibility of fame, and fame meant patronage, security, and ego-stroking. It is the culture of these people, the intellectuals in the upper tail of the human capital distribution, that mattered above all. The culture of open science they created is still with us, and it still serves science and technology well.

The beliefs of the large masses-bourgeois and peasants-obviously mattered, because they set the background parameters in which all entrepreneurs work. But beliefs of the many fewer actual actors may have mattered more. This actually provides some support for McCloskey's belief that some element of good fortune was involved in addition to circumstances and geography. As David Hume wrote in 1742 ,

Those who cultivate the sciences in any state, are always few in number: The passion, which governs them, limited: Their taste and judgment delicate and easily perverted: And their application disturbed with the smallest accident. Chance, therefore, or secret and unknown causes, must have a great influence on the rise and progress of all the refined arts (Hume 1985 [1742], 113).

Why, then, did this market work so much better in Europe than anywhere else? As McCloskey points out, following many others, the political fragmentation of Europe ensured a high level of competitiveness and made it practically impossible for any reactionary power, secular or religious, to put an end to heterodox and innovative ideas-including not only the idea that making money through hard work and ingenuity was virtuous, but also that the earth was not the 
center of the universe and that organisms did not sprout spontaneously. The reason for this success was that Europe had the best of all possible worlds. Superimposed upon the 156 separate political entities that emerged out of the Peace of Westphalia was a pan-European transnational institution known as the Respublica Literaria, a virtual network of communications (mostly through letters) and conversation of literate men and women. The Republic of Letters created an integrated European market for ideas in which intellectual innovations were discussed, vetted, tested, criticized, revealed as fraudulent or hailed as revelations. Its citizens (they actually thought of themselves in those terms) exploited the scale economies that made such an institution work precisely because it was international. The Republic of Letters was the institutional foundation of a well-functioning market for ideas. It did exactly what well-functioning institutions are supposed to do: it created the incentives and rewards for people who came up with ideas that others accepted. If this is what "trade-tested" means, I am all for it.

In my Culture of growth (2016), I discuss this market primarily in the context of beliefs regarding natural philosophy and the understanding of the physical and biological world. But McCloskey is correct in pointing out that the Great Enrichment involved a lot more than that. The profound and critical notions that triumphed in the age of enlightenment she lists are essential in understanding the Great Enrichment. First, exchange was positive-sum. If foreign nations gained from trade with your nation, that did not mean that your nation lost: both sides stood to gain. Don't fight with foreigners, trade with them. Trade beats glory. Second, rent-seeking (which was what mercantilist policies were all about) was associated with large deadweight losses. Monopolies, tariffs, subsidies, cozy offices, what the French called privilèges, were all leaky buckets in which in the gains to the winners were smaller than the losses of those who paid the price. Third, the role of government was not to enrich itself or its cronies or gain glory by hacking other people to death, but to provide the citizens with goods that the free market for one reason or another failed to supply. These are all ideas that should be associated with the European Enlightenment. Those three ideas amounted to the "institutional flip side" of the Enlightened Economy. In the end, the economic triumph of the West and the Great Enrichment cannot and should not be dissociated from the 
philosophes of the eighteenth century who collectively created the lumières. Ideas, indeed, drove the economy.

These disagreements aside, this is a magnificent book, a model of magisterial, interdisciplinary, enviably erudite scholarship. McCloskey's Bourgeois trilogy will be regarded for generations as a monument of learning and insight. Writing a review essay that does full justice to 787 pages-let alone 2,000 pages in three volumes-would be a huge task. But we should all be grateful to her for not only refuting much nonsense written about the sources of the Industrial Revolution, for bringing the humanities back into economics, but above all for her celebration of the bourgeoisie, the hard-working, creative, and decent class that has been so wrongly maligned by so many self-righteous intellectuals. It is about time someone spoke up for them-and so eloquently at that.

\section{REFERENCES}

Coase, Ronald. 1974. The market for goods and the market for ideas. American Economic Review, 64 (2): 384-91.

Cohen, H. Floris. 2012. How modern science came into the world. Amsterdam: Amsterdam University Press.

Cook, Harold J. 2007. Matters of exchange: commerce, medicine and science in the Dutch golden age. New Haven: Yale University Press.

Hume, David. 1985 [1742]. Of the rise and progress of the arts and sciences. In David Hume, Essays: moral, political and literary, ed. Eugene F. Miller. Indianapolis: Liberty Fund, 111-137.

Israel, Jonathan. 2010. A revolution of the mind. Princeton: Princeton University Press.

Jacob, Margaret C., and Larry Stewart. 2004. Practical matter: Newton's science in the service of industry and empire, 1687-1851. Cambridge (MA): Harvard University Press.

Johnson, Samuel. 1759. What have you done? (with your life). The Idler, 88: 22. http://www.ourcivilisation.com/smartboard/shop/johnsons/idler/chap88.htm (accessed May 2015).

McCloskey, Deirdre Nansen. 1985. The rhetoric of economics. Madison: University of Wisconsin Press.

McCloskey, Deirdre Nansen. 2006. The bourgeois virtues: ethics for an age of commerce. Chicago: University of Chicago Press.

McCloskey, Deirdre Nansen. 2010. Bourgeois dignity: why economics can't explain the modern World. Chicago: University of Chicago Press.

Mokyr, Joel. 2002. The gifts of Athena. Princeton: Princeton University Press.

Mokyr, Joel. 2009. The enlightened economy. New York: Yale University Press.

Mokyr, Joel. 2016. A culture of growth: the origins of the modern economy. Princeton: Princeton University Press.

Musson, Albert Edward and Eric Robinson. 1969. Science and technology in the industrial revolution. Manchester: Manchester University Press. 
Polanyi, Michael. 1962. The republic of science: its political and economic theory. Minerva, 1 (1): 54-73.

Reynolds, Terry S. 1983. Stronger than a hundred men: a history of the vertical water wheel. Baltimore: Johns Hopkins University Press.

Smith, Adam. 1976 [1759]. The theory of moral sentiments, ed. D. D. Raphael and A. L. Macfie. Oxford: Oxford University Press.

Stigler, George J. 1965. The intellectual and the marketplace. Kansas Journal of Sociology, 1 (2): 69-77.

Tomory, Leslie. 2012. Progressive enlightenment: the origins of the gaslight industry, 1780-1820. Cambridge (MA): MIT Press.

Winchester, Simon. 2001. The map that changed the world. New York: Harper Collins.

Wootton, David. 2015. The invention of science: a new history of the scientific revolution. London: Allen Lane.

Joel Mokyr is Robert H. Strotz professor of arts and sciences and professor of economics and history at Northwestern University and Sackler professor, (by special appointment) at the Eitan Berglas School of Economics, Tel Aviv University. He is also affiliated with CIFAR, the Canadian Institute for Advanced Research, and a director of the National Bureau of Economic Research. He is an economic historian with special interests in the economic history of science and technology and economic growth. His most recent books include The enlightened economy (2009) and The gifts of Athena (2002) as well as his forthcoming A culture of growth (2016).

Contact e-mail: <j-mokyr@northwestern.edu> 